\title{
Introduction: China and Latin America - Bringing the Actor Back In
}

\author{
Katja Levy ${ }^{1}$
}

Published online: 14 July 2015

(C) Journal of Chinese Political Science/Association of Chinese Political Studies 2015

Since the early 2000s, the bilateral relationship between the People's Republic of China (PRC) and the countries of Latin America and the Caribbean (LAC) has become a field of great interest in international relations. From the political science point of view, the still dominant realists' paradigm suggests that these relationships are described and analyzed mainly from a state-to-state perspective. The same thing applies to economics, where most authors show a preference for the macroeconomic analysis of these relationships (e.g. [2]).

However, there is good reason to take an intensive look at the individual and collective/ corporative actors' level in the bilateral relationship between China and LAC. ${ }^{1}$ First of all, it has been observed that states are not the only actors shaping international relations. Instead, the states' preferences are shaped by certain individual and collective actors in each country who are able to assert their interests in the internal competition with other individual and collective actors in each country, as Andrew Moravcsik [6], in his analysis of state preferences, and Robert Putnam [7], in his ground-breaking article on the logic of two-level games have convincingly explained. This is even more the case when these originally domestic actors become transnational actors acting simultaneously within a country and abroad, for example, transnational corporations and international non-governmental organizations, or when these actors go abroad and act mainly in the other country, for example, Chinese emigrants or corporate actors who settle and commit themselves to working in LAC countries. In these latter cases, the actors do not only shape their countries' foreign policies and interests at home but also act on behalf of their own interests which, even in the case of highly centralized Chinese foreign and domestic politics, are not always in accordance with state interests and policies. Analyzing the actions and interests of these individual

\footnotetext{
${ }^{1}$ Actors, in this sense, can be governments, individuals, corporations, agencies or organisations who are engaged in the bilateral relations.
}

Katja Levy

katja.levy@fu-berlin.de 
and collective actors can therefore enhance our understanding of the actual status and quality of bilateral state-to-state relations.

Secondly, the analysis of the (domestic, transnational and government) actors' behavior can help us to understand the internal situation and the preference-building of the states involved. The PRC, in particular, is very often described and perceived as a country with actors who, without exception, work together with the aim of achieving their common goal, namely the survival of the Chinese Communist Party (CCP). However, as the contributions published in this special issue of JCPS show, the actors involved are becoming more and more diverse. One approach that could be useful for examining these actors is the 'actor-oriented institutionalism' proposed by Renate Mayntz' and Fritz Scharpf ([5], 39 ff., [8]), which was originally designed to analyze political decision-making in specific policy fields in order to develop solutions for problems or to create institutions in these fields ([8], 85). According to this approach, actors are first of all characterized by certain capabilities, perceptions and preferences. However, these characteristics are not sufficient to explain how and why actors make certain political decisions. Instead, Mayntz and Scharpf introduce two more factors that play a role in shaping political decision-making and provide for a variety of possible explanations of the actors' behavior: the 'constellations of the actors' and their 'modes of interaction'. The 'constellations' describe the actors, their strategic options and the results of their combined strategic possibilities as well as their preferences. The 'mode of interaction' is not restricted to the non-cooperative mode as would be the case in game theory approaches. Instead, several further choices are possible: cooperative, coordinating (negotiation) or hierarchic mode of interaction (majority vote or hierarchical steering) ([8], $87 \mathrm{f}$.). Seen in different institutional contexts (anarchy, network, association, organization) these constellations and modes of interaction open up a plethora of possibilities for political decision-making and a way to categorize and understand them. The 'actor-oriented institutionalism' approach is therefore a useful tool for analyzing the interactions of the various actors involved in the bilateral relations between the PRC and its LAC partner countries. It can reveal, on the one hand, the motivational action orientations of the actors involved, and on the other, just how heterogeneous the involved actors are on both sides. The results can be considered crucial in the context of understanding the implications of the interactions between Chinese and Latin American actors in LAC countries.

The abundant literature on Sino-LAC relations has not, as yet, come up with much literature at this level of analysis. More recent overviews have covered a wide range of bilateral issues: the papers published in Julia Strauss' and Ariel Armony's [9] edited volume adopted mostly a classical IR unit-level state perspective, had a macroeconomic focus on certain industries or dealt with the mutual perceptions of the countries involved. Andrew Hearn's and José Luis León-Manríquez' book [4] is comprised of macro perspective country studies, while the special issue of the Journal of Contemporary Chinese Affairs on Latin America and China, edited by Jörn Dosch and David S.G. Goodman [1], offers a collection of contributions with a (mainly) macroeconomic focus, all of which remain again at the level of state-to-state economic and political relations. The same applies to R. Evan Ellis' first book on Sino-LAC relations [2]. 
In addition, a large number of individual research papers have been published, with similar focuses.

Although we have this enormously rich and informative corpus of research undertaken from the macro perspective level, micro perspective research at the actors' level is still lacking. One exception, here, is R. Evan Ellis, who with his second book on their bilateral relations [3] has given a first comprehensive account of "the Impact of the new Chinese physical presence in Latin America" ([3], 13), examining Chinese Companies in LAC countries from different angles.

The authors of this special issue of the Journal of Chinese Political Science aim to fill this gap. The papers presented in this volume were first introduced to a wider audience at a conference under the heading of "China in Latin America - who are the actors?" which took place at Freie Universität Berlin in October 2014. This conference was organized by the editor of this issue together with Enrique Dussel Peters (Universidad Nacional Autónoma de México), and generously financed by the Friedrich-Ebert-Foundation in Cooperation with Peking University and the Confucius Institute at Freie Universität Berlin. The organisers of the conference had a particular goal in mind: to address the lack of research at the micro perspective level on issues concerning the relations between China and LAC, based on the above-mentioned theoretical reflections.

The six papers that were selected for this special issue of the Journal of Chinese Political Science each adopt a particular perspective on the actors at the micro level of interaction between China and Latin America.

Julie Klinger observes the investment relations in what she refers to as the "strategic minerals" sector between the PRC and Brazil, and identifies several shifts concerning the actors and their modes of interaction as well as their constellations. While the Chinese side appears to be less unified and the Chinese state less dominant in this area, the Brazilian actors have also diversified and changed. Actors at subnational levels have become more effective in dealing with Chinese firms. She reminds us that "China is a market economy and [State Owned Enterprises] SOEs are market actors" and that China's private firms play an important role in the mining business. She also remarks on the shift of Chinese investments in the Brazilian mining sector away from a state-owned enterprise model toward the position of a minority stakeholder in already established companies. One conclusion of her study is that the research on Sino-Brazilian trade relations must be expanded beyond the state actors' level - not only up to the transnational level but also down to the sub-national actors' level.

Eduardo Oviedo studies the actors in two very diverse areas of SinoArgentinean interaction, the soybean trade and the migratory flow from China to Argentina. He shows that the state is still the strongest actor in their bilateral relations. The Chinese state acts through its trade policies on the one hand and its state-owned companies on the other. According to Oviedo's findings and in contrast to Klinger's findings in the case of the mining business, the soybean trade seems to be less diversified in terms of SOEs and private companies as well as in terms of state and SOE division. Oviedo concludes that the Argentinean state is seriously affected by the Chinese State's influence, but is still 
able to control the trade realm through its own trade policy. In contrast, in the area of migration, the Argentinean state is confronted with Chinese legal and illegal, state and non-state actors.

Bettina Gransow has linked her long term research on the development strategies of the PRC in specific infrastructure projects that have been used to develop the Chinese economy with China's current trend of undertaking vast infrastructure projects outside China, in this case in LAC countries. Her aim is to discover whether these investments are helpful in the context of the sustainable development of the region. In her careful analysis of these infrastructure projects, the actors involved, their constellations and their modes of interaction as well as their impact on the natural environment and society, she comes to the conclusion that current projects involve many environmental and social hazards and that there is a great deal of room for improvement with regard to the implementation of the already existing safeguard policies for China's outgoing infrastructure investment projects.

Yang Zhimin describes the complex constellation of the actors involved in China's efforts to tighten economic relations with LAC countries. He identifies three different kinds of Chinese actor groups - the state in its role as rule maker, the state-owned and private enterprises in their ambivalent roles as implementers of state rules, on the one hand, and as pioneers in investment and trade in the new region on the other, and finally facilitator organizations, referred to by Yang as quasi-government organizations, which serve as exchange platforms for the other two Chinese actor groups and their counterparts in LAC countries. He finds that each of these agent groups plays its particular role in "the game" and cannot be substituted by the others, thus constituting a balanced interaction network with the partner countries in Latin America, in which the Chinese state still has the greater say.

Adrian Hearn investigates the interactions of the different actors in the food sector relations between Brazil and China. He finds that the existing distrust between Brazilian actors and Chinese investors can be understood better if the diverging traditions of the two countries are taken into account. While in the West, traditions of trust stem from a history of distrust and rebellion against authority, in China, piety or great faith in authority is deeply rooted in Chinese philosophy, particularly in Confucian traditions. These differing traditions in the two countries have led to the development of divergent attitudes toward ways of gaining trust. Transparency as a means of trust-building in Western societies seems to be of minor importance for the Chinese state and also for Chinese company leaders. In the future, Hearn sees the need for new approaches to improve the 'trust relationship' between the two countries.

Finally, Ariel C. Armony and Nicolás Velásquez look at the bilateral relations between China and Argentina from a constructivist angle: they analyze the negative comments of newspaper readers in five Latin American countries in order to map the image of the PRC that is revealed by these comments. One of their findings shows that the negative perceptions of China can also be seen as a reflection of the negative sentiments concerning the development of Latin America itself. Their research reveals the importance of the mutual perceptions of public opinions in the states that are interacting in Sino-LAC relations. 
The contributions published in this issue reveal the importance and, at the same time, the complexity of undertaking research on the actors, their modes of interaction and constellations in Sino-LAC relations. This special issue and also the conference in Berlin show clearly that the research on the actors in the bilateral relations of the two countries is far from comprehensive. Many subjects have not been touched on in this issue, for example, to name but a few: what is the role of non-governmental organizations (national and transnational) in these constellations? How far can Chinese SOEs in other industries still be seen as executors of their countries' policies? What is the role of private companies? How has this role changed? How do multilateral fora, such as the China-CELAC (Community of Latin American States and the Caribbean) Forum, fit in the actor-oriented paradigm? What influence do institutional frameworks, such as the rather weakly developed Mexican legal system, have on the bilateral relations? Many more micro level field studies are required, and the methods for studying actors beyond the state level in state-to-state relations also need further development and refinement. The approach suggested here could serve as a starting point.

\section{References}

1. Dosch, Jörn, and David Goodman. 2012. China and Latin America: Complementary, competition and globalisation. Journal of Current Chinese Affairs 41(1): 3-19.

2. Ellis, R. Evan. 2009. China in Latin America: The whats and wherefores. Boulder: Lynne Rienner Publishers.

3. Ellis, R. Evan. 2014. China on the Ground in Latin America: Challenges for the Chinese and impacts. NY: Palgrave Macmillan.

4. Hearn, Adrian H., and José Luis Leon-Manriquez (eds.). 2011. China engages Latin America: Tracing the trajectory. Boulder: Lynne Rienner Publishers.

5. Mayntz, Renate, and Fritz W. Scharpf (eds.). 1995. Gesellschaftliche Selbstregelung und politische Steuerung. [Societal self-regulation and political steering]. Köln: Campus.

6. Moravcsik, Andrew. 1997. Taking preferences seriously: A liberal theory of international politics. International Organization 51(4): 513-553.

7. Putnam, Robert D. 1988. Diplomacy and domestic politics: The logic of two-level games. International Organization 42: 427-460.

8. Scharpf, Fritz W. 2006. Interaktionsformen. Akteurszentrierter Institutionalismus in der Politikforschung. Wiesbaden: VS Verlag für Sozialwissenschaften [Original edition: Scharpf, Fritz W. (1997). Games real actors play. Actor-centered institutionalism in policy research. Boulder: Westview].

9. Strauss, Julia C., and Ariel C. Armony (eds.). 2012. From the Great Wall to the New World: China and Latin America in the 21st century. Cambridge: Cambridge University Press.

Katja Levy is currently Chair of Contemporary China Studies at Julius Maximilians Universität Würzburg and Assistant Professor for Politics and Law at Freie Universität Berlin, Germany. Her research interests include China's foreign policy and domestic politics of the PRC, with a particular focus on questions related to political/social stability and social organizations. 